\title{
Banker Locus of Control
}

\author{
Dr. S. Poongavanam \\ Assistant Professor, AMET Business school, AMET University, Chennai.
}

\section{Background Of The Study}

LOC is seen as a spectrum from individuals who have an internal LOC and believe in personal ability and efforts as major determinants of outcomes to individual who have an external LOC believe in luck, fate higher powers and task difficulty as major determinants or outcomes. Therefore individuals with an internal LOC expect their actions to affects what happens to them and others while individuals with an external LOC believe that they have little influence on events.

It is important to note that people are not born as internals or externals. People develop their Locus of control as they grow through learning experience (Klienke 1991, Licourt 1976). Locus o control is based on perceptions, therefore it is not innate, and can be re-evaluated, modified or changed. As people begin to take charge, or take control of their lives they become aware that they alone can affect the outcome in their lives. Beleif in destiny or fate leads to a lack of responsibility because if one is not in control of their life, then how can they be responsible or what they do or what happens to them.

\section{Key focus of the study}

Rotter (1954) who first introduced the theory of social learning developed an extensive body of research surrounding the central construct of Locus of Control. Locus of Control is a fundamental personality trait that refers to individual differences in a generalized belief in internal versus external control of reinforcement (Rotter 1966). The main focus of the study is to identify the levels of Locus of control among different category of bank employees and their significant impact on personal variables and job related factors. However only few research scholars from management discipline attempted this study in banking industry.

\section{Internal Vs External LOC}

Individuals who believe that they control what happens to them are 'Internals' or internally motivated and have an Internal Locus of Control. Those who believe that outside factors such as luck or chance controls their fate are 'Externals' or externally motivated and have an External Locus of Control (Robins 2003). It is said that people who perform better in most employment situations generally possess a moderately strong internal rather than external locus of control. They tend to be more successful in their careers and earn more money than their external counterparts. Therefore, the control of outcomes can be perceived as located in one's own behaviours or skills or as residing in luck or chance (Rotter, 1966).

According to Howell et al, internals are particularly well suited to leadership positions and other jobs requiring initiative, independent action, complex thinking and high motivation. Internals have also been found to be more satisfied with their jobs and cope better in stressful situations, and they are more motivated by performance-based reward systems (Andrisani \& Nestel, 1976; Howell \& Avolio, 1993; Spector, 1982). Similarly, the internals were found to be interested more in research and development, introducing new products more quickly than the competition as such, and making more drastic product line changes. Furthermore, internals tend to be more involved in their jobs, show greater satisfaction, cope better with stress, and rise to leadership positions more frequently than people who are externals (Anderson, 1997; Lefcourt et al., 1984). There were many research works in the developed countries on locus of control and its impact on various job related aspects of employees in different industries. But in India, such research works are limited, particularly in banking sector. In this scenario, here an attempt has been made to elicit the status of locus of control among private and public sector bank employees in India.

\section{Statement Of Problem}

Locus of Control refers to an individual's perception of main cause of events in life. Internal control is the term used to describe the belief that control of future outcomes resides primarily in oneself while external Locus of Control refers to the expectancy that control is outside of oneself either in the hands of powerful other people or due to fate/chance. According to Rotter, total quality management does not emphasis employee needs, it focus on satisfying the customer needs. Efficiency of an organization can be improved through good compensation system, relaxation and meditation which helps employees to adjust their psychological response from stress. All the above factors play an important role and if these things are not handled properly, the employee's Locus of Control declines. If a person knows his capability he must identify his strength/weakness 
and work accordingly to the needed position and improve his personality. It leads to his development, family, organization and a great advantage to the nation. Individuals with internal Locus of Control show more overt striving for achievement than individuals with external Locus of Control. It was found that internals had higher job satisfaction and was more satisfied with a participating management style, where as externals were more satisfied with a directive style. Internals believed that working hard was more likely to lead to good performance and that good performance more likely to lead to rewards. They had more control over how they spent time on the job than did the externals. Internal had more achievement motivation, self-responsibility, high performance and low turnover. In this context it is proposed to undertake a study on the level of Locus of Control among bank employees across sector and levels.

\section{Objectives}

1. To identify the level of Locus on Control among bank employees.

2. To identify the possible differences in the Locus of Control between private and public sector banks and also between officers and managers.

3. To identify the extent of variation in Locus of Control from certain clear categories of personal variables and job related characteristics.

\section{Hypotheses}

1. There is no significant difference in the level of Locus of Control between Public and Private sector bank employees.

2. There is no significant influence of personal variables on Locus of Control.

3. There is no significant influence of job oriented factors on Locus of Control.

\section{Review of earlier studies}

Dubios Jean-Charles, Filiatrault Pierre (1984) studied the relation between locus of control and political affiliations in the context of an economic setback. The Rotter I-E Locus of Control Questionnaire was administered to 409 undergraduate students. Findings suggest that internals are more inclined to accept social and political changes and externals are more affected by economic crisis.

Lao Rosina, C., \& Bolen Larry, I. (1984) examined the effect of personality (locus of control) and situation (type of task and performance feedback) on causal attribution (acknowledgement) and emotional response. Two hundred and eight (208) male and female college students were classified into internals or externals with the use of Weiner and Potepan's IAR Scale (Intellectual Achievement Responsibility Questionnaire). Students were randomly presented either a skill or a chance task; within each task grouping, one-half received failure feedback and the other half success feedback. Each Student then completed a Likerttype rating scale containing four sets of bipolar attributes (ability, effort, luck, and task difficulty) and 10 affective labels (frustrated, surprised, relieved, pleased, disappointed, ashamed, felt better, inadequate, relaxed, and stunned) to describe their emotions while presenting performance feedback.

Parental involvement appears to be related to many desirable outcomes in adolescents. Chubb and Fertman (1992) reported that ninth-grade students who perceived belonging in their families were more likely to have internal locus of control.

Parsons (1981) has pointed out, that males tend to attribute their failures to external or unstable causes while females tend to attribute their failures to internal causes appears to be an oversimplification.

Dimitrovsky Lilly, \& Schapira-Beck Ester. (1994) studied the relationship of the differences in locus of control (LOC) to Israeli women's mood in the transition to marriage and to their marital satisfaction in the first months of marriage. Correlation between externality and depression after marriage; Change in depression scores for women with external LOC were studied..

Kalechstein Ari \& Nowicki Jr. Stephen (1994) examines the relationship between internal locus of control and achievement in telemarketers. Although it has consistently been reported that internal locus of control is related to greater academic achievement in children, such findings may not held true for adults. One possible explanation for this discrepancy is that need value may be more influential in adults' achievement behavior than in children's.

\section{Research procedure}

\section{Research Design}

After getting permission from the manager questionnaire were circulated to employees during lunch session with out affecting their business. Participants were given two/three days time to fill the questionnaire and it was collected during the same session. Participants were assured of the confidentiality of the response. Cronbach reliability test proves that the data were highly reliable and valid for further analysis. 


\section{Research Participants}

Survey method was adopted for the study and the study used both primary and secondary sources of data. The study covered eight banks in Vellore district, both private and public. The banks selected for the study are:

\section{Private sector banks}

- $\quad$ HDFC Banks

- $\quad$ ICICI Banks Ltd

- $\quad$ Karur Vysya Bank Ltd

- Axis Bank

\section{Public sector banks}

- State Bank of India

- Indian Bank

- Canara Bank

- India Overseas Bank

The sample respondents were selected from both private and public sector banks situated in Vellore district. Random sampling was adopted to choose the desired sample size. Employees were stratified into Officers and Managers and the respondents 260 (194 officers and 76 managers) were selected from the selected public and private sector banks. The distribution of selected sample respondents is given in the following table:

Table 1 - Sample Distribution

\begin{tabular}{|l|l|l|l|l|l|}
\hline Sl. No. & Name of Bank & Sector & Manager & Officers & Total \\
\hline 1 & HDFC Bank & Private & 4 & 17 & 21 \\
\hline 2 & ICICI Bank Ltd. & Private & 2 & 27 & 29 \\
\hline 3 & Karur Vysya Bank Ltd. & Private & 10 & 15 & 25 \\
\hline 4 & Axis Bank & Private & 3 & 21 & 24 \\
\hline & & & & & \\
\hline Total & & Public & 19 & 10 & 90 \\
\hline 1 & State Bank India & Public & 14 & 25 & 35 \\
\hline 2 & Indian Bank & Public & 8 & 38 & 32 \\
\hline 3 & Canara Bank & Public & 15 & 33 & 41 \\
\hline 4 & Indian Overseas Bank & & 47 & 114 & 33 \\
\hline & & & $\mathbf{6 6}$ & $\mathbf{1 9 4}$ & 161 \\
\hline $\begin{array}{l}\text { Grand } \\
\text { Total }\end{array}$ & & & & $\mathbf{2 6 0}$ \\
\end{tabular}

Tools used for analysis

1. $\operatorname{Mean}(\bar{X})$

$$
\bar{X}=\frac{\sum X_{i}}{n}
$$

Where, $X_{i}$ is opinion score of respondent ' $i$ ' and ' $n$ ' is number of observations (respondents)

\section{Standard Deviation $(\sigma)$}

$$
\sigma=\sqrt{\frac{\sum X_{i}^{2}}{n}-(\bar{X})^{2}}
$$
mean score.

Where, $\mathrm{X}_{\mathrm{i}}$ is opinion score of respondent ' $\mathrm{i}$ ', ' $\mathrm{n}$ ' is number of observations (respondents) and $\bar{X}$ is

\section{Kruskal-Wallis test}

The Kruskal Wallis test, sometimes called $\mathrm{H}$ test, is an alternative procedure to a one-way ANOVA. The Kruskal-Wallis test assumes that the population variances are equal. Unlike an ANOVA test, the KruskalWallis nonparametric alternative can be used with ordinal or ranked data. The Kruskal Wallis test calculates ' $\mathrm{H}$ ' value as test statistics. In order to calculate, $\mathrm{H}$ value using Kruskal Wallis test, first place the combined observations, $y_{\mathrm{ij}}$, into order of magnitude and replace with their ranks, $R_{\mathrm{ij}}$. Then calculate the sum of the ranks for the responses to each treatment, $\mathrm{Ri}$ and then calculate $\mathrm{H}$ using the following formula: 


$$
\begin{aligned}
& \mathrm{H}=\frac{1}{\mathrm{~S}^{2}}\left[\sum_{\mathrm{i}=1}^{\mathrm{a}} \frac{\mathrm{R}_{\mathrm{i} .}^{2}}{\mathrm{n}_{\mathrm{i}}}-\frac{\mathrm{N}(\mathrm{N}+1)^{2}}{4}\right] \\
& \text { Where } \mathrm{S} 2=\frac{1}{\mathrm{~N}-1}\left[\sum_{\mathrm{i}=1}^{\mathrm{a}} \sum_{\mathrm{j}=1}^{\mathrm{n}_{\mathrm{i}}} \mathrm{R}_{\mathrm{ij}}^{2}-\frac{\mathrm{N}(\mathrm{N}+1)^{2}}{4}\right]
\end{aligned}
$$

$\mathrm{N}=$ Number of total observations

\section{F test}

The F test, i.e., One Way Analysis of Variance is used to ascertain statistical significance of the difference in mean perception among three groups or more. The formula for calculating ratio of variance or simply ' $F$ ' is

$$
F=\frac{S_{B}^{2}}{S_{W}{ }^{2}}
$$

Where,

$$
\begin{array}{lll}
\mathrm{F} & = & \text { Ratio of variance (F Value) } \\
S_{B}{ }^{2} & = & \text { Between group variance } \\
S_{w}{ }^{2} & = & \text { Within group variance }
\end{array}
$$

\section{Chi-square test}

Chi-square is an important non-parametric test and as such no rigid assumptions are necessary in respect of the type of population.

$$
x^{2}=\sum \frac{(\text { observed } \times \text { frequency }- \text { expected } \times \text { frequency })^{2}}{(\text { expected } \times \text { frequency })}
$$

\section{Instrumentation}

In this study the standard tool developed by Terry Pettijohn was used to find out the Locus of Control among employees of public and private sector banks situated in Vellore district.

The questionnaire consisted of Two parts. In the first part certain background data were sought in order to identify the personal and job related variables. In the second part each respondent was asked to respond to the 20 statement pertinent to locus of control, using the Likert type 5 point scoring system ranging from strongly agree to strongly disagree.

\section{Reliability and Validity Test}

\section{Result}

The status of locus of control among bank employees was measured using 20 statements in the questionnaire. The respondents were asked to indicate their degree of agreement with each statement, using a 5point Likert scale ranging from ' 1 ' for "strongly disagree" to ' 5 ' for "strongly agree" and '2' for "disagree", ' 3 ' for "no opinion" (neither agree nor disagree) and '4' for "agree" in between. The reliability (internal consistency) of the scale items measuring locus of control is first examined with Cronbach's alpha reliability coefficient. Cronbach's alpha ranges from zero to one, with value 'zero' indicating complete unreliability and value 'one' indicating perfect reliability. Each item's correlation with total scores as well as "alpha if deleted" is also calculated in order to identify the consistency of each item in the measurement scale. The results of the analysis are shown in Table 2. 
Table - 2 Reliability and Validity of the Scale Items Measuring Locus of Control

\begin{tabular}{|c|c|c|c|}
\hline Ż & Item Description & $\begin{array}{c}\text { Item to } \\
\text { Total } \\
\text { Correlation } \\
\end{array}$ & Alpha if Deleted \\
\hline 1 & I usually get what I want in life & 0.59 & 0.9259 \\
\hline 2 & I need to be kept informed about news events & 0.60 & 0.9259 \\
\hline 3 & I never know where I stand with other people & 0.63 & 0.9250 \\
\hline 4 & I do not really believe in luck or chance & 0.56 & 0.9266 \\
\hline 5 & I think that I could easily win a lottery & 0.63 & 0.9251 \\
\hline 6 & If I do not succeed on a task, I tend to given up & 0.58 & 0.9261 \\
\hline 7 & I usually convince other to things my way & 0.64 & 0.9249 \\
\hline 8 & People make a difference in controlling crime & 0.63 & 0.9252 \\
\hline 9 & The success I have is largely a matter of chance & 0.63 & 0.9251 \\
\hline 10 & Marriage is largely a gamble for most people & 0.66 & 0.9246 \\
\hline 11 & People must be the master of their own fate & 0.74 & 0.9228 \\
\hline 12 & It is not important for me to vote & 0.65 & 0.9246 \\
\hline 13 & My life seems like a series of random events & 0.58 & 0.9261 \\
\hline 14 & I never try anything that I am not sure of & 0.61 & 0.9255 \\
\hline 15 & I earn the respect and honours I receive & 0.59 & 0.9260 \\
\hline 16 & A person can get rich by taking risk & 0.58 & 0.9261 \\
\hline 17 & Leaders are successful when they work hard & 0.53 & 0.9271 \\
\hline 18 & Persistence and hard work usually leads to success & 0.55 & 0.9267 \\
\hline 19 & It is difficult to know who my real friends are & 0.60 & 0.9257 \\
\hline 20 & Other people usually control my life & 0.55 & 0.9266 \\
\hline \multicolumn{2}{|c|}{ Cronbach's Alpha Reliability Coefficient } & \multicolumn{2}{|c|}{0.9290} \\
\hline
\end{tabular}

Source: Primary Data

It can be observed from Table 2 that item to total correlation ranges between 0.53 and 0.74 , indicating consistent pattern of sufficient positive correlations of at least a value of 0.30 . The item to total correlation is the Pearson " $r$ " of each item with the total score on all items, which acts as a discrimination index for each item. If the item correlates highly with the total score it is internally consistent and should be retained. If a zero or very low correlation coefficient is obtained, it indicates that the statement is not discriminating between groups and referred as undifferentiating.

Further, Cronbach's alpha reliability coefficient of the locus of control measurement scale items is 0.9290 and near to 'one', revealing that there has been high degree of internal consistency among 20 items in the scale measuring locus of control of bank employees. Hence, it is found that the scale items measuring locus of control measurement are highly reliable, internally consistent and the collected data can be used for subsequent analysis.

To examine the validity and dimensionality in the locus of control, principal component factor analysis with varimax rotation is applied. The results of the factor analysis are presented in Table 3 and 4.

Table 3 is provided with eigenvalue, percent of total variance and cumulative percent of total variance for factors underlying the locus of control. The eigenvalue for a given factor measures the variance in all the variables which is accounted for by that factor. If a factor has a low eigenvalue, then it is contributing little to the explanation of variances in the variables and may be ignored as redundant with more important factors. According to Kaiser (1960) criterion, which is probably the one most widely used, the factor with eigenvalue above 'one' is valid factor and retained for further analysis. 
TABLE -3 Eigenvalues of Factors Underlying Scale Items Measuring Locus of Control among Bank Employees

\begin{tabular}{|c|c|c|c|}
\hline Underlying Factors & Eigenvalue & $\%$ total Variance & $\begin{array}{c}\text { Cumulative } \% \text { of } \\
\text { Variance. }\end{array}$ \\
\hline 1 & 8.59 & 42.94 & 42.94 \\
\hline 2 & 2.80 & 14.02 & 56.96 \\
\hline 3 & 1.11 & 5.53 & 62.50 \\
\hline 4 & 0.83 & 4.16 & 66.66 \\
\hline 5 & 0.68 & 3.41 & 70.07 \\
\hline 6 & 0.64 & 3.18 & 73.25 \\
\hline 7 & 0.55 & 2.77 & 76.02 \\
\hline 8 & 0.53 & 2.65 & 78.66 \\
\hline 9 & 0.48 & 2.42 & 81.09 \\
\hline 10 & 0.44 & 2.20 & 83.29 \\
\hline 11 & 0.43 & 2.15 & 85.44 \\
\hline 12 & 0.41 & 2.03 & 87.47 \\
\hline 13 & 0.40 & 2.00 & 89.46 \\
\hline 14 & 0.37 & 1.84 & 91.30 \\
\hline 15 & 0.35 & 1.76 & 93.06 \\
\hline 16 & 0.33 & 1.64 & 94.70 \\
\hline 17 & 0.32 & 1.59 & 96.30 \\
\hline 18 & 0.30 & 1.48 & 97.78 \\
\hline 19 & 0.26 & 1.29 & 99.07 \\
\hline 20 & 0.19 & 0.93 & 100.00 \\
\hline
\end{tabular}

Source: Primary Data

As per table, the initial eigenvalues for first, second and third factors are 8.59, 2.80 and 1.11 respectively. That is, the eigenvalue is above 'one' for first three factors and hence they are valid factors. The percentage variance explained by each of the three factors is 42.94, 14.02 and 5.53 with cumulative percentage of 62.50. The number of extractable factors is also illustrated using Scree plot (Figure 4.2).

Figure 1

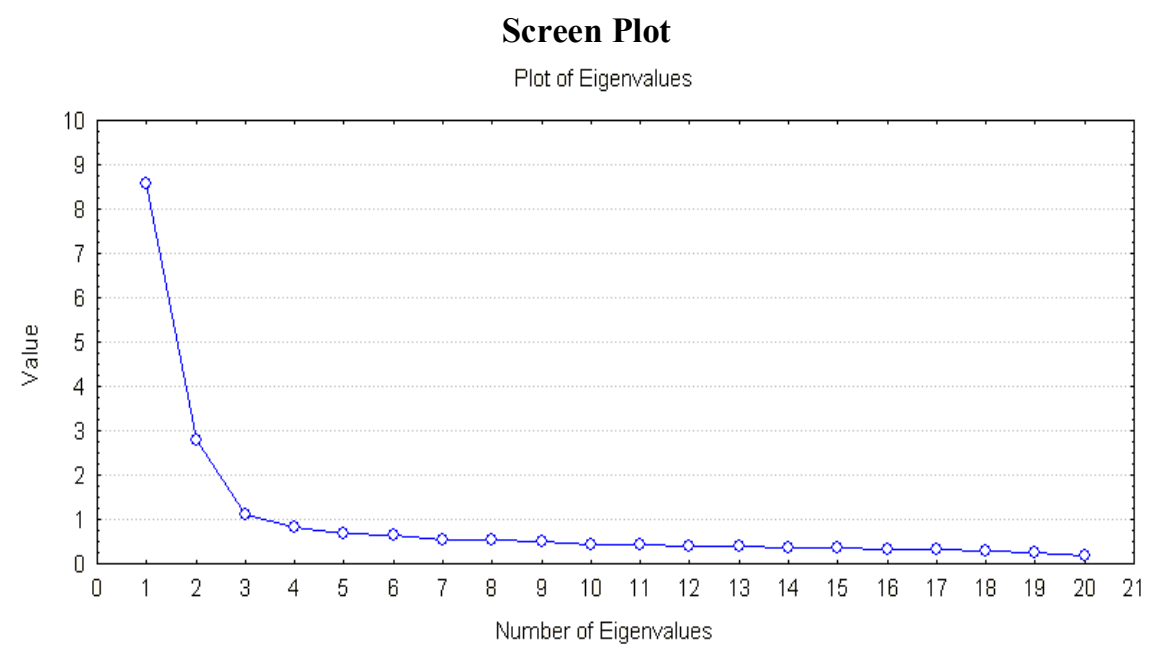

The Scree plot is the plot of eigenvalues in their decreasing order. The plot looks like the side of mountain, and "screen" refers to the debris fallen from a mountain and lying at its base. So the screen test proposes to stop analysis at the point the mountain ends and the debris (error) begins. In the above Screen plot the mountain point ends at eigenvalue ' 1 ', which is also coinciding with Kaiser Criterion. Hence, it is undoubtedly concluded that locus of control among bank employees comprises of three dimensions.

Table 4 presents factor loadings of each item on three valid factors after varimax rotation. The factor loadings are the correlations between the variables (items) and the extracted factors, and ranges between -1 and +1 . 
Table - 4 Items loadings with Extracted Factors after Varimax Rotation

\begin{tabular}{|c|c|c|c|c|}
\hline \multirow{2}{*}{ 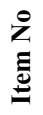 } & \multirow{2}{*}{ Item Description } & \multicolumn{3}{|c|}{ Factor } \\
\hline & & 1 & 2 & 3 \\
\hline 1 & I usually get what I want in life & 0.60 & & \\
\hline 2 & I need to be kept informed about news events & 0.72 & & \\
\hline 3 & I never know where I stand with other people & 0.76 & & \\
\hline 4 & I do not really believe in luck or chance & 0.69 & & \\
\hline 5 & I think that I could easily win a lottery & 0.81 & & \\
\hline 6 & If I do not succeed on a task, I tend to given up & 0.76 & & \\
\hline 7 & I usually convince other to things my way & 0.74 & & \\
\hline 8 & People make a difference in controlling crime & 0.75 & & \\
\hline 14 & I never try anything that I am not sure of & 0.72 & & \\
\hline 15 & I earn the respect and honours I receive & & 0.75 & \\
\hline 16 & A person can get rich by taking risk & & 0.85 & \\
\hline 17 & Leaders are successful when they work hard & & 0.84 & \\
\hline 18 & Persistence and hard work usually leads to success & & 0.82 & \\
\hline 9 & The success I have is largely a matter of chance & & & 0.68 \\
\hline 10 & Marriage is largely a gamble for most people & & & 0.64 \\
\hline 11 & People must be the master of their own fate & & & 0.61 \\
\hline 12 & It is not important for me to vote & & & 0.57 \\
\hline 13 & My life seems like a series of random events & & & 0.66 \\
\hline 19 & It is difficult to know who my real friends are & & & 0.63 \\
\hline 20 & Other people usually control my life & & & 0.69 \\
\hline \multirow{3}{*}{\multicolumn{2}{|c|}{$\begin{array}{l}\text { Explained Variance } \\
\% \text { of Total Variance }\end{array}$}} & 5.31 & 3.72 & 3.47 \\
\hline & & 26.55 & 18.58 & 17.37 \\
\hline & & 26.55 & 45.13 & 62.50 \\
\hline \multicolumn{2}{|c|}{ Factor Label } & 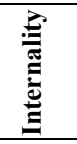 & 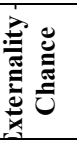 & 预 \\
\hline
\end{tabular}

Source: Primary Data

Varimax rotation is an orthogonal rotation of the factor axes to maximize the variance of the squared loadings of a factor (column) on all the variables (rows) in a factor matrix, which has the effect of differentiating the original variables by extracted factor. Each factor will tend to have either large or small loadings of any particular variable. A varimax solution yields results which make it as easy as possible to identify each variable with a single factor. This is the most common rotation option. The Rotation actually helps to make the output more understandable and is usually necessary to facilitate the interpretation of factors. The sum of eigenvalues is not affected by rotation, but rotation will alter the eigenvalues (and percent of variance explained) of particular factors and will change the factor loadings.

According to table, the eigenvalues of factors have changed to 5.31, 3.72 and 3.47 and at the same time leaving the total variance the same $(62.50 \%)$ after varimax rotation. After rotation, the percentage variance explained by first, second and third factors $26.55,18.58$ and 17.37. From the observation of factor loadings, it is understood that the first factor is highly correlated with items from 1 to 8 and with item 14 . Similarly, the second factor has high correlation with items $15-18$ and third factors with items from 9 to 13,19 and 20. For first factor, the loading of item 5 is the highest of all followed by items $3 \& 6,8,7,2 \& 14,4$ and 1 . Based on the above loadings, the first factor is named as "Internality Locus of Control". Similarly, the second and third factors are labeled as "Chance externality" and "Powerful other externality". The scores of items for each factor are averaged and average scores are used in the empirical analysis for findings the status of locus of control among bank employees on the whole as well as by sectors and also for identifying the influence of personal and job characteristics variables on the locus of control. The results of the analysis are tabulated and discussed in detail in the following part of this chapter.

The level of Internality, Externality - chance, and Externality - powerful others of locus of control among Public, Private and All Bank employees, is evaluated based on the respondents' mean perception scores, which are presented in Table 5. 
Table 5 Status of Locus of Control among Bank Employees

\begin{tabular}{|c|c|c|c|c|}
\hline Dimensions of Locus of Control & $\mathbf{N}$ & Mean & SD & Z Value \\
\hline \multicolumn{5}{|c|}{ Public Sector Banks } \\
\hline Internality & 161 & 3.47 & 0.77 & $7.64 * * *$ \\
\hline Externality - Chance & 161 & 3.56 & 0.77 & $9.24 * * *$ \\
\hline Externality - Powerful Others & 161 & 3.74 & 0.86 & $10.93 * * *$ \\
\hline \multicolumn{5}{|c|}{ Private Sector Banks } \\
\hline Internality & 99 & 3.57 & 0.74 & $7.64 * * *$ \\
\hline Externality - Chance & 99 & 3.67 & 0.67 & $9.98 * * *$ \\
\hline Externality - Powerful Others & 99 & 3.82 & 0.81 & $10.09 * * *$ \\
\hline \multicolumn{5}{|c|}{ All Banks (Total Sample) } \\
\hline Internality & 260 & 3.51 & 0.76 & $10.70 * * *$ \\
\hline Externality - Chance & 260 & 3.60 & 0.73 & $13.25 * * *$ \\
\hline Externality - Powerful Others & 260 & 3.77 & 0.84 & $14.79 * * *$ \\
\hline
\end{tabular}

$\mathrm{Z}$ table value $@ 10 \%=1.64, @ 5 \%=1.96$ and $@ 1 \%=2.57$

$* * *$ Significant at $1 \%$ level.

From table, it can be observed that the mean scores vary from 3.47 to 3.74 for public sector bank employees, 3.57 to 3.82 for private sector bank employees and 3.51 to 3.77 for whole sample. The mean score is found to be beyond ' 3 ', the value for neutral (neither agree nor disagree level) for all dimensions of locus of control. $\mathrm{Z}$ values are calculated for ascertaining the significance of the difference between observed mean score and hypothetical value, 3. It is evident that all $\mathrm{Z}$ values are significant highly at 1 per cent level. From the significant $Z$ values, and the mean score above 3 , it is confirmed that there exists internality, chance externality and powerful other externality of locus of control among public and private bank employees.

\section{Effect Of Personal-Job Characteristics On LOC}

An influence of age, sex, marital status, education and family size as well as the influence of designation, monthly income, experience in present position, bank experience and nature of work on internality, chance externality and powerful other externality of the locus of control for entire sample is evaluated here.

The mean opinion, rank sums and KW test statistic results comparing the internality of the locus of control among bank employees by personal characteristics are portrayed in Table 6 . It can be seen from table that the level of internality of the locus of control is similar for all age groups (Mean scores vary between 3.48 and 3.54, $\mathrm{H}$ value is very trivial). The level of the above LOC is seen to be more for female $(\mathrm{Mean}=3.60)$ and unmarried (Mean =3.65) employees whereas it seems to be considerably less for employees with higher to PG education $($ Mean $=3.35)$ and for those from large size families (Mean =3.35) compared to their counterparts.

Table - 6 Effect of Personal Variables on Locus of Control - Internality for All Bank Employees

\begin{tabular}{|c|c|c|c|c|c|c|}
\hline & Personal Variables & $\mathbf{N}$ & Mean & Rank Sum & $\begin{array}{c}\text { Kruskal- Wallis } \\
\text { 'H' }\end{array}$ & 'p' Value \\
\hline 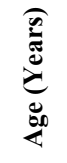 & $\begin{array}{l}\text { Up to } 25 \\
26-35 \\
36-45 \\
\text { Above } 45\end{array}$ & $\begin{array}{l}44 \\
89 \\
67 \\
60\end{array}$ & $\begin{array}{l}3.54 \\
\\
3.50 \\
3.51 \\
3.48\end{array}$ & $\begin{array}{r}5893.5 \\
11553.5 \\
8802.5 \\
7680.5\end{array}$ & 0.18 & 0.98 \\
\hline$\ddot{D}$ & $\begin{array}{l}\text { Male } \\
\text { Female }\end{array}$ & $\begin{array}{r}192 \\
68\end{array}$ & $\begin{array}{l}3.47 \\
3.60 \\
\end{array}$ & $\begin{array}{r}24420.5 \\
9509.5\end{array}$ & 1.43 & 0.23 \\
\hline 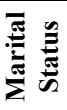 & $\begin{array}{l}\text { Married } \\
\text { Unmarried }\end{array}$ & $\begin{array}{r}177 \\
83\end{array}$ & $\begin{array}{l}3.44 \\
3.65\end{array}$ & $\begin{array}{l}22013.0 \\
11917.0\end{array}$ & $3.70 * *$ & 0.05 \\
\hline : & $\begin{array}{l}\text { Graduate } \\
\text { Post Graduate } \\
\text { Higher to PG }\end{array}$ & $\begin{array}{r}134 \\
84 \\
42\end{array}$ & $\begin{array}{l}3.52 \\
3.56 \\
3.35\end{array}$ & $\begin{array}{r}17598.0 \\
11478.5 \\
4853.5\end{array}$ & 2.24 & 0.33 \\
\hline 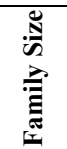 & $\begin{array}{l}\text { Up to } 3 \text { members } \\
4-6 \text { members } \\
\text { Above } 6 \text { members }\end{array}$ & $\begin{array}{r}146 \\
95 \\
19\end{array}$ & $\begin{array}{l}3.49 \\
3.56 \\
3.35\end{array}$ & $\begin{array}{r}18899.0 \\
12814.5 \\
2216.5\end{array}$ & 1.00 & 0.61 \\
\hline
\end{tabular}

Source: Primary Data. **Significant at $5 \%$ level. 
But, the $\mathrm{KW}-\mathrm{H}$ values obtained from comparing the rank sum scores across categories by all personal variables except by marital status are not significant statistically. At the same time, the difference in the level of above LOC is significant at 5 per cent level $(\mathrm{H}=3.70, \mathrm{p}<0.05)$. On the whole, it is found that internality of locus of control is independent of their age, sex, education and family size but it differs significantly between married and unmarried bank employees.

Table 7 depicts the results of the analysis revealing the significance of the association between joboriented variables and internality of locus of control among bank employees.

Table 7 Effect of Job Oriented Factors on Locus of Control - Internality for All Bank Employees

\begin{tabular}{|c|c|c|c|c|c|c|}
\hline \multicolumn{2}{|r|}{ Job Related Factors } & $\mathbf{N}$ & Mean & Rank Sum & $\begin{array}{c}\text { Kruskal- Wallis } \\
\text { 'H' }\end{array}$ & 'p' Value \\
\hline \multirow{2}{*}{ مِ } & Managers & 66 & 3.62 & 9425.0 & \multirow[t]{2}{*}{2.37} & \multirow[t]{2}{*}{0.12} \\
\hline & Officers & 194 & 3.47 & 24505.0 & & \\
\hline \multirow{3}{*}{ 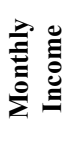 } & Up to Rs. 20000 & 109 & 3.45 & 13527.5 & \multirow{3}{*}{$5.35^{*}$} & \multirow{3}{*}{0.07} \\
\hline & Rs.20000-30000 & 102 & 3.63 & 14644.5 & & \\
\hline & Above Rs.30000 & 49 & 3.37 & 5758.0 & & \\
\hline \multirow{4}{*}{ 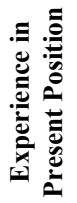 } & Up to 5 Years & 86 & 3.49 & 11190.5 & \multirow{4}{*}{0.20} & \multirow{4}{*}{0.98} \\
\hline & $6-10$ Years & 89 & 3.52 & 11595.5 & & \\
\hline & $11-15$ Years & 63 & 3.49 & 8126.5 & & \\
\hline & $>15$ Years & 22 & 3.56 & 3017.5 & & \\
\hline \multirow{4}{*}{ 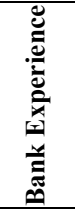 } & Up to 5 Years & 48 & 3.51 & 6380.5 & \multirow{4}{*}{0.20} & \multirow{4}{*}{0.98} \\
\hline & $6-10$ Years & 42 & 3.52 & 5515.5 & & \\
\hline & $11-15$ Years & 85 & 3.49 & 10849.5 & & \\
\hline & $>15$ Years & 85 & 3.52 & 11184.5 & & \\
\hline \multirow{3}{*}{ 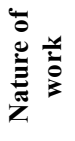 } & Mutual Fund & 47 & 3.57 & 6367.0 & \multirow{3}{*}{0.48} & \multirow{3}{*}{0.79} \\
\hline & Insurance & 86 & 3.45 & 10871.0 & & \\
\hline & Banking & 127 & 3.52 & 16692.0 & & \\
\hline
\end{tabular}

Source: Primary Data. *Significant at $10 \%$ level.

It seems from table that as the mean opinion scores are above 3 , in the agree range and they are similar across all categories by designation, experience in present position, bank experience and family size. The insignificant $\mathrm{H}$ values for the above personal variables have statistically supported the similarity in the level of internality in the LOC among bank employees. On the other hand, the level of internality of the locus of control is found to be significantly less among bank employees with monthly income above Rs.30000 (Mean = 3.37) as the KW test statistics ' $\mathrm{H}$ ', 5.35 is significant at 10 per cent level. In sum, it is found that the level of internality of the locus of control among bank employees differ significantly by monthly income but it is unaffected by their designation, experience in present position, bank experience and nature of work.

The effects of personal characteristics on chance externality of the locus of control among bank employees are analyzed and the results of the analysis are presented in Table 8.

From table, it is apparent that the chance externality of the locus of control is almost same among respondent groups of all family sizes (Mean values are almost equal and $\mathrm{H}$ value is near to zero). Similar scenario as above is visible when compared by educational status of the bank employees. However, the level of chance externality of the locus of control is less for younger (aged up to 25 years - Mean $=3.48$ ) employees compared to elder groups (Aged above 45 years - Mean $=3.70)$, more for female $($ Mean $=3.70)$ relative to male $($ Mean $=3.57)$ and higher for unmarried employees (Mean $=3.73$ compared to that of those in the married groups $($ Mean $=3.54)$. 
Table - 8 Effect of Personal Variables on Locus of Control - Externality (Chance) for All Bank Employees

\begin{tabular}{|c|c|c|c|c|c|c|}
\hline & Personal Variables & $\mathbf{N}$ & Mean & Rank Sum & $\begin{array}{c}\text { Kruskal- Wallis } \\
\text { 'H' }\end{array}$ & 'p' Value \\
\hline \multirow{4}{*}{ 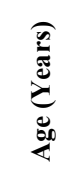 } & Up to 25 & 44 & 3.48 & 5297.5 & \multirow{4}{*}{1.62} & \multirow{4}{*}{0.66} \\
\hline & $26-35$ & 89 & 3.59 & 11553.5 & & \\
\hline & $36-45$ & 67 & 3.61 & 8725.0 & & \\
\hline & Above 45 & 60 & 3.70 & 8354.0 & & \\
\hline \multirow{2}{*}{ ڤ્ } & Male & 192 & 3.57 & 24392.0 & \multirow[t]{2}{*}{1.56} & \multirow[t]{2}{*}{0.21} \\
\hline & Female & 68 & 3.70 & 9538.0 & & \\
\hline \multirow{2}{*}{ 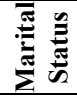 } & Married & 177 & 3.54 & 21999.0 & \multirow[t]{2}{*}{$3.80 * *$} & \multirow[t]{2}{*}{0.05} \\
\hline & Unmarried & 83 & 3.73 & 11931.0 & & \\
\hline \multirow{3}{*}{ 氖 } & Graduate & 134 & 3.57 & 17128.5 & \multirow{3}{*}{0.46} & \multirow{3}{*}{0.80} \\
\hline & Post Graduate & 84 & 3.62 & 11071.5 & & \\
\hline & Higher to PG & 42 & 3.68 & 5730.0 & & \\
\hline \multirow{3}{*}{ 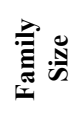 } & Up to 3 members & 146 & 3.59 & 18907.5 & \multirow{3}{*}{0.08} & \multirow{3}{*}{0.96} \\
\hline & $4-6$ members & 95 & 3.62 & 12561.0 & & \\
\hline & Above 6 members & 19 & 3.62 & 2461.5 & & \\
\hline
\end{tabular}

Source: Primary Data.

But, the calculated $\mathrm{H}$ value for the difference in rank sum scores is significant only for marital status $(\mathrm{H}$ $=3.80, \mathrm{p}<0.05)$. So, it is found that the marital status of the bank employees has significant effect on the level of chance externality of the locus of control and age, sex, education and family size do not have any influence on it.

Table 9 gives the results of the analysis for relationship between job related factors and chance externality of the locus of control among bank employees.

Table 9 Effect of Job Oriented Factors on Locus of Control - Externality (Chance) for All Bank Employees

\begin{tabular}{|c|c|c|c|c|c|c|}
\hline \multicolumn{2}{|r|}{ Job Related Factors } & $\mathbf{N}$ & Mean & Rank Sum & \begin{tabular}{|c|} 
Kruskal- Wallis \\
'H'
\end{tabular} & 'p' Value \\
\hline مِّ & $\begin{array}{l}\text { Managers } \\
\text { Officers }\end{array}$ & $\begin{array}{r}66 \\
194\end{array}$ & $\begin{array}{l}3.62 \\
3.60\end{array}$ & $\begin{array}{r}8660.0 \\
25270.0\end{array}$ & 0.01 & 0.93 \\
\hline 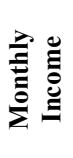 & $\begin{array}{l}\text { Up to Rs. } 20000 \\
\text { Rs. } 20000-30000 \\
\text { Above Rs.30000 }\end{array}$ & $\begin{array}{r}109 \\
102 \\
49\end{array}$ & $\begin{array}{l}3.52 \\
3.76 \\
3.45\end{array}$ & $\begin{array}{r}13445.0 \\
14846.5 \\
5638.5\end{array}$ & $7.17 * *$ & 0.03 \\
\hline 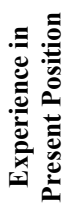 & $\begin{array}{l}\text { Up to } 5 \text { Years } \\
6-10 \text { Years } \\
11-15 \text { Years } \\
>15 \text { Years }\end{array}$ & $\begin{array}{l}86 \\
89 \\
63 \\
22\end{array}$ & $\begin{array}{l}3.55 \\
3.65 \\
3.55 \\
3.75\end{array}$ & $\begin{array}{r}11078.5 \\
11866.5 \\
7831.0 \\
3154.0\end{array}$ & 1.25 & 0.74 \\
\hline 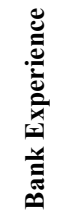 & $\begin{array}{l}\text { Up to } 5 \text { Years } \\
6-10 \text { Years } \\
11-15 \text { Years } \\
>15 \text { Years }\end{array}$ & $\begin{array}{l}48 \\
42 \\
85 \\
85\end{array}$ & $\begin{array}{l}3.55 \\
3.63 \\
3.65 \\
3.57\end{array}$ & $\begin{array}{r}6210.0 \\
5642.5 \\
11372.5 \\
10705.0\end{array}$ & 0.60 & 0.90 \\
\hline 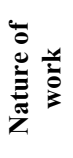 & $\begin{array}{l}\text { Mutual Fund } \\
\text { Insurance } \\
\text { Banking }\end{array}$ & $\begin{array}{r}47 \\
86 \\
127\end{array}$ & $\begin{array}{l}3.67 \\
3.46 \\
3.67\end{array}$ & $\begin{array}{r}6494.5 \\
9927.5 \\
17508.0\end{array}$ & $5.18 *$ & 0.08 \\
\hline
\end{tabular}

Source: Primary Data. *Significant at 10\% level; **Significant at 5\% level. 
It is evident from table that there is no any difference in the level of chance externality of the locus of control between managers and officers as mean scores as well as among respondent categories by bank experience ( $\mathrm{H}$ value is almost zero for designation and very small for nature of work). Somewhat similar picture as above can be seen in the case of respondent groups by experience in the present position $(\mathrm{H}$ value $=$ 1.25 and not significant).

But the level of chance externality of the locus of control is significantly higher for bank employees with income between Rs.20000-30000 per month (Mean $=3.76$; $\mathrm{H}$ value $=7.17, \mathrm{p}<0.05$ ). Similarly, the level of chance externality of the LOC is found to be significantly less for employees doing insurance work (Mean = 3.46) as $\mathrm{H}$ value of 5.18 is significant at 10 per cent level. Hence, overall it is found that the level of chance externality of locus of control among bank employees is significantly influenced by their income and nature of work and it is independent of their designation, experience in present position and experience in bank.

The status of powerful other externality of the locus of control among bank employee groups by age, sex, marital status, education and family size is compared using $\mathrm{KW}$ test and the results of the analysis are shown in Table 9. From the perusal of the table, it is understand that the level of powerful other external tendencies (locus of control) is not same for all age groups. The younger employees (aged up to 25 years) tend to show significantly low level of powerful other externality of the LOC compared to those in other age groups $(\mathrm{H}$ value $=7.55, \mathrm{p}<0.10)$

Table - 10 Effect of Personal Variables on Locus of Control - Externality (Powerful Others) for All Bank Employees

\begin{tabular}{|c|c|c|c|c|c|c|}
\hline & Personal Variables & $\mathbf{N}$ & Mean & Rank Sum & $\begin{array}{c}\text { Kruskal- Wallis } \\
\text { 'H' }\end{array}$ & 'p' Value \\
\hline \multirow{4}{*}{ 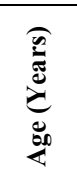 } & Up to 25 & 44 & 3.59 & 5030.5 & \multirow{4}{*}{$7.55^{*}$} & \multirow{4}{*}{0.06} \\
\hline & $26-35$ & 89 & 3.74 & 11323.0 & & \\
\hline & $36-45$ & 67 & 3.72 & 8441.5 & & \\
\hline & Above 45 & 60 & 4.01 & 9135.0 & & \\
\hline \multirow{2}{*}{$\stackrel{\circlearrowright}{0}$} & Male & 192 & 3.75 & 24638.0 & \multirow[t]{2}{*}{0.62} & \multirow[t]{2}{*}{0.43} \\
\hline & Female & 68 & 3.83 & 9292.0 & & \\
\hline \multirow{2}{*}{ 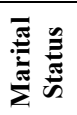 } & Married & 177 & 3.77 & 23224.5 & \multirow[t]{2}{*}{0.05} & \multirow[t]{2}{*}{0.82} \\
\hline & Unmarried & 83 & 3.77 & 10705.5 & & \\
\hline \multirow{3}{*}{ 氖 } & Graduate & 134 & 3.72 & 16963.0 & \multirow{3}{*}{0.76} & \multirow{3}{*}{0.68} \\
\hline & Post Graduate & 84 & 3.80 & 11279.5 & & \\
\hline & Higher to PG & 42 & 3.86 & 5687.5 & & \\
\hline \multirow{3}{*}{ 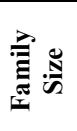 } & Up to 3 members & 146 & 3.73 & 18523.5 & \multirow{3}{*}{1.27} & \multirow{3}{*}{0.53} \\
\hline & $4-6$ members & 95 & 3.86 & 13047.0 & & \\
\hline & Above 6 members & 19 & 3.66 & 2359.5 & & \\
\hline
\end{tabular}

Source: Primary Data.

But the level of locus of control due to powerful other external factors is similar for male and female, married and unmarried bank employee as well as it is similar irrespective of education and family size because $\mathrm{H}$ values for all the above personal variables are insignificant. Therefore, it may be concluded that the level of powerful other externality of the locus of control differ significantly by age and similar by sex, marital status, education and family size for bank employees.

The results comparing the level of locus of control tendencies towards powerful other externals among respondent groups by job characteristics are shown in Table 11

Table 11Effect of Job Oriented Factors on Locus of Control - Externality (Powerful Others) for All Bank Employees

\begin{tabular}{|c|c|c|c|c|c|c|}
\hline \multicolumn{2}{|r|}{ Job Related Factors } & $\mathbf{N}$ & Mean & Rank Sum & $\begin{array}{c}\text { Kruskal- Wallis } \\
\text { ' } H \text { ' }\end{array}$ & 'p' Value \\
\hline 它 & $\begin{array}{l}\text { Managers } \\
\text { Officers }\end{array}$ & $\begin{array}{r}66 \\
194 \\
\end{array}$ & $\begin{array}{l}3.79 \\
3.76\end{array}$ & $\begin{array}{r}8611.5 \\
25318.5\end{array}$ & 0.00 & 1.00 \\
\hline 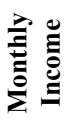 & $\begin{array}{l}\text { Up to Rs. } 20000 \\
\text { Rs.20000-30000 }\end{array}$ & $\begin{array}{l}109 \\
102\end{array}$ & $\begin{array}{l}3.67 \\
3.94\end{array}$ & $\begin{array}{l}13430.5 \\
14672.5\end{array}$ & $5.46^{*}$ & 0.07 \\
\hline
\end{tabular}




\begin{tabular}{|c|c|c|c|c|c|c|}
\hline & Above Rs. 30000 & 49 & 3.64 & 5827.0 & & \\
\hline 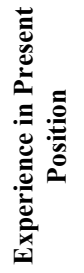 & $\begin{array}{l}\text { Up to } 5 \text { Years } \\
6-10 \text { Years } \\
11-15 \text { Years } \\
>15 \text { Years }\end{array}$ & $\begin{array}{l}86 \\
89 \\
63 \\
22\end{array}$ & $\begin{array}{l}3.70 \\
3.78 \\
3.82 \\
3.84\end{array}$ & $\begin{array}{r}10910.0 \\
11784.5 \\
8301.0 \\
2934.5\end{array}$ & 0.31 & 0.96 \\
\hline 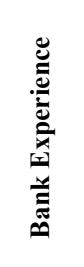 & $\begin{array}{l}\text { Up to } 5 \text { Years } \\
6-10 \text { Years } \\
11-15 \text { Years } \\
>15 \text { Years }\end{array}$ & $\begin{array}{l}48 \\
42 \\
85 \\
85\end{array}$ & $\begin{array}{r}3.70 \\
3.78 \\
3.83 \\
3.75 \\
\end{array}$ & $\begin{array}{r}6107.0 \\
5685.5 \\
11286.5 \\
10851.0\end{array}$ & 0.47 & 0.93 \\
\hline 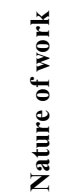 & $\begin{array}{l}\text { Mutual Fund } \\
\text { Insurance } \\
\text { Banking }\end{array}$ & $\begin{array}{r}47 \\
86 \\
127\end{array}$ & $\begin{array}{r}3.76 \\
3.60 \\
\\
3.89\end{array}$ & $\begin{array}{r}6026.0 \\
10171.5 \\
17732.5\end{array}$ & 4.23 & 0.12 \\
\hline
\end{tabular}

Source: Primary Data.

An observation of table reveals that the level of powerful other externality of the locus of control is similar between managers and officers as mean scores are almost equal and $\mathrm{H}$ value is zero. It is also similar for employees groups with all years of experience in present position and banking ( $\mathrm{H}$ values are trivial). But, the above locus of control is found to be more among respondents with monthly income between Rs.20000-30000 $($ Mean $=3.97), 11-15$ years of experience in the present position (Mean $=3.99)$ and it is found to be less among employees doing insurance job compared to that of their counterparts. But $\mathrm{H}$ value is significant at 10 per cent level for monthly income $(\mathrm{H}=7.62, \mathrm{p}<0.05)$ and insignificant for nature of work $(\mathrm{H}=4.23, \mathrm{p}>0.10$, not significant). So, from the above entire picture, it is identified that the level of powerful other externality of locus of control among bank employees is significantly influenced by their income level and it is unaffected by other job characteristics.

\section{Cluster Analysis For Grouping Respondents By Level Of LOC}

The cluster analysis is generally used to identify relatively homogenous group of subjects based on selected characteristics. The subjects in a cluster are like each other and they are different from subjects in other clusters. Here, this multivariate technique is used to group the bank employees with similar level of internality, chance externality and powerful other externality of the locus of control. In this study, the cluster analysis group the respondents in to three mutually exclusive groups with low, moderate and high level of locus of control. This is carried out to compare the level of locus of control between private and public sector bank as well as to identify the relationship ship between level of locus of control and level of job involvement in the forthcoming chapter.

Table 12 produces the results of cross tabulation with chi-square analysis comparing the number of cases with low, moderate and high level of internality of the locus of control between public and private sector banks.

Table - 12 Comparison of Level of Internality Locus of Control by Banking Sector

\begin{tabular}{|c|c|c|c|c|c|}
\hline \multirow{2}{*}{ Banking Sector } & \multicolumn{3}{|c|}{ Level of Internality } & \multirow{2}{*}{ All } & \multirow{2}{*}{ Chi-Square } \\
\hline & Low & Moderate & High & & \\
\hline Public & $\begin{array}{c}53 \\
(32.9)\end{array}$ & $\begin{array}{c}53 \\
(32.9)\end{array}$ & $\begin{array}{c}55 \\
(34.2)\end{array}$ & $\begin{array}{c}161 \\
(100.0)\end{array}$ & $\begin{array}{c}1.81^{\mathrm{NS}} \\
\mathrm{df}=2\end{array}$ \\
\hline Private & $\begin{array}{c}25 \\
(25.3)\end{array}$ & $\begin{array}{c}38 \\
(38.4)\end{array}$ & $\begin{array}{c}36 \\
(36.4)\end{array}$ & $\begin{array}{c}99 \\
(100.0)\end{array}$ & \\
\hline All & $\begin{array}{c}78 \\
(30.0)\end{array}$ & $\begin{array}{c}91 \\
(35.0)\end{array}$ & $\begin{array}{c}91 \\
(35.0)\end{array}$ & $\begin{array}{c}260 \\
(100.0)\end{array}$ & \\
\hline
\end{tabular}


Source: Primary Data. $\mathrm{df}=$ Degrees of freedom. NS - Not significant

Figures in brackets are percentages to row total.

An examination of the table shows that number of cases with moderate and high $(36.4 \%)$ level of internality is higher in private banks $(38.4 \%)$, while the cases with low $(32.9 \%)$ level of internality is more in public sector banks. However, the above difference in the group membership across three different level of internality is only due to chance as the obtained chi-square value, 1.81 with 2 degrees of freedom is insignificant. Therefore, it can be postulated that there is no difference in the level of internal locus of control tendencies between public and private sector bank employees.

The results of cross tabulation analysis along with chi-square values for the difference in observed frequencies between public and private sector banks across low, moderate and high level of chance externality of the locus of control are shown in Table 13.

Table - 13 Comparison of Level of Chance Externality Locus of Control by Banking Sector

\begin{tabular}{|l|c|c|c|c|c|}
\hline \multirow{2}{*}{ Banking Sector } & \multicolumn{3}{|c|}{ Level of Chance Externality } & \multirow{2}{*}{ All } & \multirow{2}{*}{ Chi-Square } \\
\cline { 2 - 4 } & Low & Moderate & High & & \\
\hline \multirow{2}{*}{ Public } & 49 & 47 & 65 & 161 & $2.10^{\text {NS }}$ \\
& $(30.4)$ & $(29.2)$ & $(40.4)$ & $(100.0)$ & $\mathrm{df}=2$ \\
\multirow{2}{*}{ Private } & 22 & 33 & 44 & 99 & \\
& $(22.2)$ & $(33.3)$ & $(44.4)$ & $(100.0)$ & \\
\multirow{2}{*}{ All } & 71 & 80 & 40.37 & 260 & \\
& $(27.3)$ & $(30.8)$ & $(15.5)$ & $(100.0)$ & \\
\hline
\end{tabular}

Source: Primary Data. $\mathrm{df}=$ Degrees of freedom. NS - Not significant

Figures in brackets are percentages to row total.

An observation of the table reveals that the number of respondents with low level of chance externality in public sector banks is more than that of those in private banks. But number of moderate and high opinion cases is higher in private banks compared to public sector banks. This shows that there is difference in the level of chance externality between public and private sector bank employees. But the chi-square value, 2.10 for the difference in observed cases across three level of chance externality is insignificant. Hence, it is concluded that there is no difference in the level of chance externality of the locus of control between public and private sector bank employees.

Table 14 presents the cross tabulation / chi-square analysis results comparing the level of powerful other externality of the locus of control between public and private sector bank employees.

Table - 14 Comparison of Level of Powerful Other Externality Locus of Control by Banking Sector

\begin{tabular}{|l|c|c|c|c|c|}
\hline \multirow{2}{*}{ Banking Sector } & \multicolumn{3}{|c|}{ Level of Other Externality } & \multirow{2}{*}{ All } & \multirow{2}{*}{ Chi-Square } \\
\cline { 2 - 4 } & Low & Moderate & High & & \\
\hline \multirow{2}{*}{ Public } & 51 & 60 & 50 & 161 & $0.07 \mathrm{NS}$ \\
& $(31.7)$ & $(37.3)$ & $(31.1)$ & $(100.0)$ & $\mathrm{df}=2$ \\
Private & 30 & 37 & 32 & 99 & \\
& $(30.3)$ & $(37.4)$ & $(32.3)$ & $(100.0)$ & \\
\hline \multirow{2}{*}{ All } & 81 & 97 & 82 & 260 & \\
& $(31.2)$ & $(37.3)$ & $(31.5)$ & $(100.0)$ & \\
\hline
\end{tabular}

Source: Primary Data. $\mathrm{df}=$ Degrees of freedom. NS - Not significant

Figures in brackets are percentages to row total.

It is observed from table that percentage of respondents with low, moderate and high level of powerful other externality is almost same in both public and private sector banks. Further, calculated chi-square value for the difference in observed cases between public and private sector banks across three levels of powerful other externality is near to zero, supporting the above fact. So, it is concluded that the level of powerful other externality of the locus of control is similar between public and private sector bank employees.

\section{Discussion}

The research study made an attempt to identify the level of Locus of Control among employee. In particular it tries to find the possible differences in Locus of Control among private sector and public sector bank employees. Based on factor loading three factors were identified viz., Internality Locus of Control, Chance Externality \& Powerful other Externality. 


\section{Public sector bank employees}

The result of the analysis shows that personal variables does not has any impact on Internality Locus of control but monthly income has significant impact at 10\% level on externality(chance) locus of control. Age has significant impact on externality (Powerful others) at $1 \%$ level and Monthly income has significant impact at $5 \%$ level. This shows that age and monthly income of employees has some significant role.

\section{Private sector bank employees}

Family size has significant impact at $10 \%$ level on Internality Locus of control; Designation has significant impact on 5\% level on Internality. It may be due to the risk faced the managers of private sector bank . Nature of work has significant impact at $5 \%$ level on externality (chance).

\section{All Bank employees}

Marital status and monthly income has significant at 5\% and $10 \%$ level respectively on internality LOC. Marital status, Nature of work and Monthly income has significant impact at 5\% level on Externality(chance), but age has significant impact at 10\% level on externality (powerful others) .Even through there are some significant impact but the level of locus of control is similar among public and private sector bank employees.

\section{Limitation of the study}

The sample is drawn from eight banks in Vellore district and generalization of result of the study to a wider population should be done with caution.

The sample size is limited to 260 and certain difficulties are encountered while collecting data.

\section{Conclusion}

From inferences of the results of the analysis, so far it is concluded that the locus of control among bank employees consists of three broad aspects, namely internality, chance externality and powerful other externality. When considered bank employees on the whole, the locus of control tendencies, whether it is related to internality, chance externality or powerful other externality, are at notable level. It is concluded that marital status has significant influence on the internality locus of control and chance externality locus of control, while age has remarkable influence on other externality locus of control. On the other hand, all aspects of locus of control tendencies (internality, chance externality and powerful other externality) among bank employees differ significantly by their income. It is finally concluded the level of locus of control is similar between public and private second bank employees.

\section{Reference}

[1]. Dubios Nicole. (1985). The Dimensionality of Locus of Control Among French Students. Journal of Psychology, Vol. 119 Issue 6, p549.

[2]. Lao Rosina, C., \& Bolen Larry. (1984). Attributions and emotions as functions of locus of control, task, and feedback. Journal of social psychology, vol. 122 issue 2, p285.

[3]. Dimitrovsky Lilly, \& Schapira-Beck Ester. (1994). Locus of control of Israeli women during the transition to marriage. Journal of Psychology, Vol. 128 Issue 5, p537.

[4]. Abel Bruce, J., Hayslip Jr. Bert.,(1986). Locus of Control and Attitudes Toward Work and Retirement. Journal of Psychology, 120 (5), p479.

[5]. Agrawal Rita, Kaur Jasbir, (1985). Anxiety and Adjustment Levels Among the Visually and Hearing Impaired and Their Relationship to Locus of Control, Cognitive, Social, and Biographical Variables. Journal of Psychology, 119(3), p265.

[6]. Beckham Crystal, M., Spray Beverly, J., Pietz Christina, A. (2007). Jurors' Locus of Control and Defendants' Attractiveness in Death Penalty Sentencing. Journal of Social Psychology, Vol. 147 Issue 3, p285-298.

[7]. Boone Christophe, De Brabander Bert. (1993). Generalized Vs.Specific Locus of Control expectancies of chielf executive officers. Strategic Management Journal, Vol. 14 Issue 8, p619-625.

[8]. Bradley Graham, L., Sparks Beverley, A. (2002). Service Locus of Control: Its Conceptualization and Measurement. Journal of Service Research, Vol. 4 Issue 4, p312.

[9]. Butcher Elizabeth, \& Hebert David, J. (1985). Locus of Control Similarity and Counselor Effectiveness: A Matched Case Study. Journal of Counseling \& Development, Vol. 64 Issue 2, p103.

[10]. Chebat Jean-Charles. (1986). Social Responsibility, Locus of Control, and Social Class.. Journal of Social Psychology, Vol. 126 Issue 4, p559.

[11]. Chebat Jean-Charles, Zuccaro Cataldo, \& Filiatrault Pierre. (1992). Locus of Control as a Moderator Variable for the Attribution and Learning Processes of Marketing Managers. Journal of Social Psychology, Vol. 132 Issue 5, p597-608.

[12]. Dimitrovsky Lilly, \& Schapira-Beck Ester. (1994). Locus of control of Israeli women during the transition to marriage. Journal of Psychology, Vol. 128 Issue 5, p537.

[13]. Galejs Irma, \& Pease Damaris. (1986). Parenting Beliefs and Locus of Control Orientation. Journal of Psychology, Vol. 120 Issue 5, p501.

[14]. Johnson Avis, L., Luthans Fred, \& Hennessey Harry, W. (1984). The role of locus of control in leader influence behavior. Personnel Psychology, Vol. 37 Issue 1, p61-75.

[15]. Lester David, Castromayor Iris, J., \& Içli Tülin. (1991). Locus of Control, Depression, and Suicidal Ideation Among American, Philippine, and Turkish Students. Journal of Social Psychology, Jun91, Vol. 131 Issue 3, p447-449. 
[16]. Lian-Hwang Chiu. (1988). Locus of Control Differences Between American and Chinese Adolescents. Journal of Social Psychology, Vol. 128 Issue 3, p411.

[17]. Magwaza, A. S., \& Bhana, K. (1991). Stress, Locus of Control, and Psychological Status in Black South African Migrants. Journal of Social Psychology, Vol. 131 Issue 2, p157-164.

[18]. Nwachukwu Osita, C. (1995). CEO locus of control, strategic planning, differentiation, and small business performance: A test... Journal of Applied Business Research, Vol. 11 Issue 4, p9.

[19]. Srinivasan Narasimhan, \& Tikoo Surinder. (1992) Effect of locus of control on information search behavior. Advances in Consumer Research, Vol. 19 Issue 1, p498.

[20]. Ward Edward, A. (1992). Locus of Control of Small Business Managers. Journal of Social Psychology, Vol. 132 Issue 5, p687-689. 